Beyond Philology No. 16/4, 2019

ISSN 1732-1220, eISSN 2451-1498

https://doi.org/10.26881/bp.2019.4.06

\title{
Problems in medical translation among professional and non-professional translators: Collocations as a key issue
}

\author{
ARKADIUSZ BADZIŃSKI
}

Received 03.09.2018, received in revised form 01.09.2019,

accepted 04.09.2019.

\begin{abstract}
English is currently the lingua franca in medicine, especially due to the development of new terms that combine the medical field with technical areas. The aim of this study is to compare the problems encountered by professional and non-professional translators (physicians) with special attention paid to collocations. Further valuable observations and comments are also added by the respondents. The paper discusses the key position of collocations in the medical register in which the erroneous use of collocations discredits the paper and the researcher, thus hindering the dissemination of medical knowledge. Additionally, some other problematic issues are also highlighted. The author postulates further collocation-related empirical studies with attention paid to the phenomena of both teaching collocations and assessing the competence of the translator in the domain of collocations.
\end{abstract}

\section{Key words}

medical translation, medical collocations, medical language, medical translator, medical register 


\title{
Problemy związane $z$ tłumaczeniem medycznym wśród tłumaczy zawodowych oraz tłumaczy niezajmujących się zawodowo przekładem. Kolokacje jako kluczowe zagadnienie
}

\begin{abstract}
Abstrakt
Język angielski obecnie pełni rolę lingua franca w medycynie, zwłaszcza ze względu na rozwój nowych terminów łączących dziedzinę medycyny $z$ dziedzinami technicznymi. Celem badania jest porównanie problemów, które napotkają tłumacze zawodowi oraz lekarze, którzy samodzielnie dokonuja przekładu tekstów medycznych, ze szczególnym uwzględnieniem kolokacji. Kolejne cenne spostrzeżenia i komentarze są również dołączone przez respondentów. W artykule omówiono nadrzędna pozycję kolokacji w rejestrze medycznym, w którym błędne zastosowanie kolokacji dyskredytuje artykuł oraz badacza, utrudniając w ten sposób upowszechnianie wiedzy medycznej. Dodatkowo podkreślono również inne problematyczne kwestie. Autor postuluje dalsze badania empiryczne w zakresie problematyki kolokacji $z$ uwzględnieniem zjawisk zwiazanych $z$ ich nauczaniem i ocenianiem kompetencji tłumacza w zakresie znajomości kolokacji.
\end{abstract}

\section{Słowa kluczowe}

tłumaczenie medyczne, kolokacje medyczne, język medyczny, tłumacz medyczny, rejestr medyczny

\section{Introduction}

According to Lee-Jahnke (1998: 87) and Niebrój (2010: 13), the English language has become the lingua franca in the world of medicine. In the $21^{\text {st }}$ century in particular, technological innovations are omnipresent. Some terms related to these innovations are also employed in the world of medicine, particularly in cardiology, ophthalmology, nano-medicine or bio-engineering, with the result that an immense progression of medical vocabulary is observed. Such rapid development was obviously 
initiated at the end of the $19^{\text {th }}$ century, however, it was the $20^{\text {th }}$ century in particular, which saw the expansion of medical terminology into fields such as oncology or radiology (c.f. Badziński 2007: 235). Furthermore, new specialties came into existence (e.g. hypertensiology). Consequently, some of the most rapidly developing medical specialties, such as cardiac surgery, neurosurgery, nano-medicine or genetics, have contributed to the interdisciplinary connection between medical and para-medical specialties (e.g. bio-statistics). The multiplication of single lexemes and longer expressions (i.e. two, three or four word phrases) was also noted. These terms are translated mostly from English into other languages and, as a result, they become incorporated in the general medical register.

The language of medicine has been analyzed by a number of specialists in the field such as Lee-Jahnke (1998), Montalt (2007), Džuganová (2013), Pilegaard (2016), and Karwacka (2016). Different lexical relationships in the medical field have also been studied by various Polish authors, e.g. Wysocka (2001), Kokot (2001), Leśniewska (2008), and Badziński (2010).

As Montalt (2007: 156) rightly states, medical specialties may be characterized by different norms in terms of terminology. It should be kept in mind that the contemporary division into more than 40 basic specialties (including hypertensiology or psycho-oncology) has resulted in the formation of a wide variety of lexemes that are typical and characteristic of one field exclusively (e.g. genetics). Over time, obviously, such terminology is incorporated into the general medical terminology or it may be typically limited to the original field (e.g. cardiology, ophthalmology).

\section{The aim of the study}

The aim of the study was to analyse problems in medical translation which are experienced by both professional translators and physicians who are non-professional translators involved in the process of doing medical translation of their own manuscripts. A survey questionnaire was used as a research tool in 
the present study in order to obtain information regarding the key problems related to medical translation and subsequently to analyse the most frequent components mentioned by the respondents based on the prepared survey questionnaire. Due to the fact that certain obstacles occur in the process of specialized translation, an in-depth analysis is believed to be useful in the translation process as it highlights certain problematic domains and, in consequence, hopefully offers some solutions for the future.

\section{Material and method}

The survey was conducted between January 2017 and May 2017. Thirty-nine respondents were enrolled in the study. The word translator in the present study refers both to medical translators who are experts in their field by profession and to physicians who translate their own manuscripts for publication. The former group therefore was labelled as professional translators (8), whereas the latter one was defined as non-professional translators (31). The term non-professional was deliberately chosen because physicians usually do not possess formal knowledge related to translation, nor are they familiar with certain translation strategies.

For the purpose of the study, the following auto-definition of the term translator was adopted, i.e. medical translators who perceive their role in such a way and who were working as medical translators at the time of the study. The exclusion criteria were as follows: former experience in translation with no present participation in the process of translation for over a year and/or experience in conference medical interpreting (as it could cause potential interactions between translation and interpreting, hence the results in the survey might be related to both processes). No further exclusion criteria were employed.

None of the physicians had a language background in terms of formal language studies. Seven of them (23\%), however, passed the Cambridge Advanced Examination (CAE) and two of them $(<1 \%)$ the Cambridge Proficiency Examination (CPE), 
which according to the Common European Framework of Reference for Languages, equates to the $\mathrm{C} 1$ and $\mathrm{C} 2$ levels, respectively.

As far as professional translators were concerned, all of them (8) were graduates of the English Studies Departments from different Polish universities. None of them, however, had any medical background or any other professional association with medicine (except for translation) that could potentially affect the survey results, nor did they have any post-graduate medical-related studies.

The total number of respondents who were provided with the survey questionnaire was initially 42. However, three of them did not return the survey questionnaire with their answers for unknown reasons (all respondents had previously given their consent to participate in the study). Therefore, the final total number of respondents was 39, 19 women and 20 men, between the ages of 32 and 53. All of the professional translators had at least four years of experience in medical translation either from working as freelance translators or from providing services to translation agencies. In the group of non-professionals, the physicians had at least three years of experience in translation and their experience as medical doctors ranged from 4 to 24 years.

Both groups were provided with the anonymous survey questionnaire to assess the problems encountered in the process of translation. The respondents were also asked to share further comments if problems they had experienced were not included in the questionnaire.

The questions in the questionnaire survey were divided into two subsections. The first was connected with the characteristics of the respondents (age, years of experience in translation and the number of translated articles). The second subsection was related to the detailed analysis of key problematic issues. All of the survey participants were requested to comment only on issues related to their English language use due to the fact that the interference of other non-native languages could be a factor potentially adversely affecting the results of the questionnaire survey. 
As the main goal was to reach active translators who are practically involved in the process of translation, the survey questionnaire was distributed among physicians from the medical universities of Silesia, Katowice and Zabrze. In the case of professional translators, dissemination was via translation agencies in Poland.

The questionnaire survey was prepared specifically for the purpose of the study and was exactly the same for both study groups, except for the question related to work experience, where in the case of physicians the question of medical experience was provided in addition to the question of translation experience.

In the case of professional translators, the mean number of translated articles per respondent was 11 per year, whereas in the case of non-professional translators it was four per year. It should be noted that the majority of translations were sent to international journals (82.7\%) with an Impact Factor of at least 1.2. The remaining translations $(17.3 \%)$ were submitted to Polish journals which do not have an Impact Factor. In the section allotted to additional comments, a significant number of survey participants (seven; 18\%; three translators and four physicians) noted that their manuscripts had been rejected due to low quality of language as indicated by reviewers. This is of great importance to the present study.

In the case of physicians who do their translation themselves, none of them had translated any article that was outside of the domain of their own specialty. The articles which were translated in cooperation with the specialists from other fields (e.g. statisticians) were also considered. This cooperation was due to the fact that some parts of medical manuscripts (such as elements of statistics) frequently require the assistance of other experts. That issue was mentioned by five respondents (physicians). It should be remembered that statistics as a separate scientific discipline has its own terminology, which may also be difficult for physicians. As a result, some physicians delegate the statistical part to statisticians, as indicated in the additional comments in the questionnaire. 
The medical specialties translated by professional translators who were survey participants were as follows: neurology, oncology, paediatrics, radiology, surgery, laryngology and dermatology. Physician respondents translated articles in the fields of cardiology, oncology, neurology, diabetology, psychiatry, surgery, nephrology, haematology, and public health.

Due to the fact that non-professional translators (physicians) may not necessarily be familiar with the technical terms used in linguistics (e.g. passive voice, collocations, register), some examples were provided to illustrate the meaning where necessary for question clarity.

Special attention was paid to the clarity and transparency of the questions in order to avoid ambiguity. The questions were formulated in English, in an approachable manner without referring to highly specialized translation terminology.

Open questions were generally avoided except for the final question in which the respondents were asked to express their further comments related to the process of translation. Interestingly, some of these comments were very important as they indicated problems which had not been previously included in the questionnaire (e.g. medical register).

Next to the items included in the survey questionnaire, a score of 1-5 points was also included to indicate the frequency of a particular problem. Table 1 presents the complete survey questionnaire.

Table 2 provides the questionnaire results with the number of respondents who indicated particular problems and the scores of the problem intensity.

Note: For the purposes of clarity and visibility the problem specified in the table is given with a shorter description (for further details: please see Table 1). Please note that the table with the most problematic issue is in bold.

No (no) - number; N/a - not applicable; Nc - not calculated 
Table 1

The survey questionnaire related to the most common problems encountered in the process of translating medical texts

\begin{tabular}{|c|c|c|}
\hline \multicolumn{3}{|c|}{ CHARACTERISTICS } \\
\hline \multicolumn{3}{|c|}{$\begin{array}{l}\text { B. Years of experience in clinical practice } \\
\text { (for physicians only) } \ldots \ldots \ldots \ldots \ldots \ldots \ldots \ldots \\
5 . \text { Number of translated articles: } \ldots \ldots \ldots \ldots \ldots \ldots \ldots \ldots \ldots \\
\quad 6 . \text { Medical specialties which were translated: }\end{array}$} \\
\hline No. & Problems related to & $\begin{array}{l}\text { Please, also indicate the } \\
\text { frequency of the problems } \\
\text { - score } 0-5 \text { where } \\
0=\text { no problems } \\
1=\text { some minor problems } \\
2=\text { rarely problematic } \\
3=\text { quite problematic } \\
4=\text { frequently problematic } \\
5=\text { highly problematic }\end{array}$ \\
\hline 1. & use of tenses & \\
\hline 2. & $\begin{array}{l}\text { use of passive voice (e.g. was } \\
\text { verified, was further analyzed, } \\
\text { has been mentioned etc.) }\end{array}$ & \\
\hline 3. & $\begin{array}{l}\text { a large number of noun } \\
\text { phrases }\end{array}$ & \\
\hline 4. & $\begin{array}{l}\text { length of sentences in the } \\
\text { Polish language }\end{array}$ & \\
\hline 5. & $\begin{array}{l}\text { lack of appropriate tools (e.g. } \\
\text { glossary, dictionary) }\end{array}$ & \\
\hline 6. & $\begin{array}{l}\text { finding an appropriate gram- } \\
\text { mar construction in the Eng- } \\
\text { lish language }\end{array}$ & \\
\hline 7. & articles $-(a /$ an $/$ the $)$ & \\
\hline
\end{tabular}




\begin{tabular}{|l|l|l|}
\hline 8. & prepositions (on/at/in/by) & \\
\hline 9. & $\begin{array}{l}\text { collocations, i.e. fixed combina- } \\
\text { tions of lexical items, e.g. }\end{array}$ & \\
& $\begin{array}{l}\text { - transilluminated scrotal } \\
\text { swelling } \\
\text { - replaced by supplementation } \\
\text { - concurrent zinc deficiency } \\
\text { - stocking-glove distribution } \\
\text { deficit }\end{array}$ & \\
\hline 10. & other problems & \\
\hline 11. & no problems & \\
\hline
\end{tabular}

Table 2

Problems related to medical translation as indicated by both study groups.

\begin{tabular}{|c|c|c|c|c|c|c|c|}
\hline \multirow[b]{2}{*}{ No. } & \multirow[b]{2}{*}{ 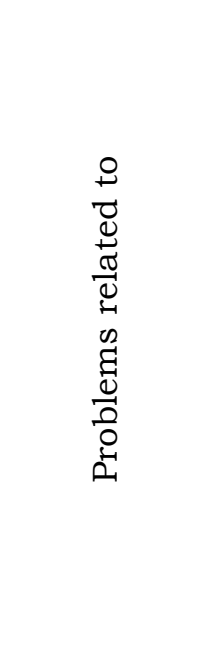 } & \multirow{2}{*}{ 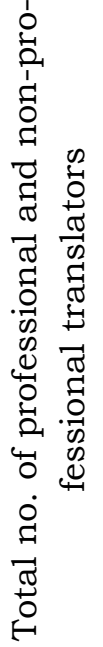 } & \multicolumn{2}{|c|}{ No. of } & \multirow{2}{*}{ 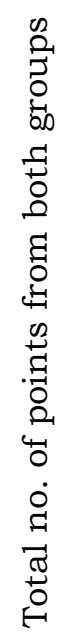 } & \multicolumn{2}{|c|}{$\begin{array}{l}\text { No. of points } \\
\text { given by }\end{array}$} \\
\hline & & & $\begin{array}{l}0 \\
0 \\
0 \\
0 \\
0 \\
0 \\
0 \\
0 \\
0 \\
\sigma \\
0 \\
0 \\
0 \\
0 \\
0 \\
0 \\
0 \\
0\end{array}$ & 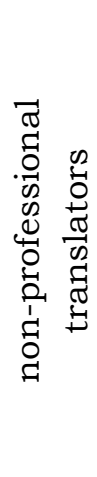 & & 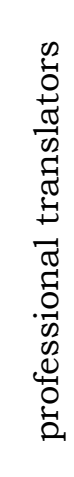 & 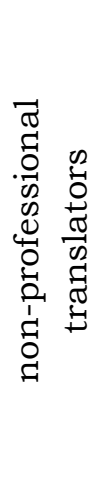 \\
\hline 1. & $\begin{array}{l}\text { use of } \\
\text { tenses }\end{array}$ & 9 & 2 & 7 & 34 & 6 & 28 \\
\hline 2. & $\begin{array}{l}\text { use of pas- } \\
\text { sive voice }\end{array}$ & - & - & - & - & - & - \\
\hline 3. & $\begin{array}{l}\text { a large } \\
\text { number of } \\
\text { noun } \\
\text { phrases }\end{array}$ & 5 & 3 & 2 & 10 & 7 & 3 \\
\hline
\end{tabular}




\begin{tabular}{|c|l|c|c|c|c|c|c|}
\hline 4. & $\begin{array}{l}\text { length of } \\
\text { sentences } \\
\text { in the } \\
\text { Polish lan- } \\
\text { guage }\end{array}$ & 18 & 6 & 12 & 22 & 10 & 12 \\
\hline 5. & $\begin{array}{l}\text { lack of ap- } \\
\text { propriate } \\
\text { tools (e.g. } \\
\text { glossary, } \\
\text { dictionary) }\end{array}$ & 5 & 3 & 2 & 17 & 11 & 6 \\
\hline 6. & $\begin{array}{l}\text { finding an } \\
\text { appropri- } \\
\text { ate gram- } \\
\text { mar con- } \\
\text { struction } \\
\text { in English }\end{array}$ & 21 & 6 & 15 & 68 & 27 & 41 \\
\hline 7. & articles & 19 & 6 & 13 & 40 & 11 & 29 \\
\hline 8. & $\begin{array}{l}\text { preposi- } \\
\text { tions }\end{array}$ & 23 & 6 & 17 & 64 & 18 & 46 \\
\hline $\mathbf{9 .}$ & $\begin{array}{l}\text { colloca- } \\
\text { tions }\end{array}$ & $\mathbf{2 3}$ & $\mathbf{7}$ & $\mathbf{1 6}$ & $\mathbf{7 2}$ & $\mathbf{3 3}$ & $\mathbf{3 9}$ \\
\hline 10. & $\begin{array}{l}\text { other pro- } \\
\text { blems }\end{array}$ & 11 & 3 & 8 & $\mathrm{Nc}$ & $\mathrm{Nc}$ & $\mathrm{Nc}$ \\
\hline 11. & $\begin{array}{l}\text { no pro- } \\
\text { blems }\end{array}$ & 3 & 1 & 2 & $\mathrm{~N} / \mathrm{a}$ & $\mathrm{N} / \mathrm{a}$ & $\mathrm{N} / \mathrm{a}$ \\
\hline
\end{tabular}

\section{Results}

Ninety-three percent of the survey questionnaires were completed and returned, which is representative, considering the fact that no other studies on medical collocations have been conducted on such samples in Poland as yet. The study revealed interesting results in both groups, namely problems related to collocations.

Of note, as many as 11 respondents (28\%) provided their additional comments regarding the observations connected with the process of translation. Furthermore, two opinions are of great significance as they pay attention to the interdisciplinary 
nature of the articles that were translated (oncology-neurology and cardiology-diabetology).

Survey respondents indicated problems with all of the issues listed in the questionnaire except, surprisingly, the passive voice. The detailed characteristics of the results are presented in Table II. The following were given the most attention: tenses (9; professional translators-2, physicians-7), articles $(19 ; 6 / 13)$ prepositions $(23 ; 6 / 17)$, a large number of noun phrases $(5 ; 3 / 2)$, the length of the sentence (especially in the mother tongue - L1) $(18 ; 6 / 12)$, inability (impossibility) to find the appropriate grammar structure in the target language (L2) $(21,6 / 15)$, lack of the appropriate tool (e.g. glossary) (5; 3/2), collocations (23; 7/16). Interestingly, three respondents (one professional translator and two physicians) had no difficulties related to the translation of articles, which was indicated in the questionnaire.

However, when the score related to the difficulty of particular components was assessed, the results were different. For the purpose of the present study, each point from the total number of 1-5 was calculated. Therefore, the total number of points for each component was as follows: 34 points for tenses (professional translators-6, physicians-28), 40 for articles (11/29), 64 for prepositions (18/46), 10 for a large number of noun phrases (7/3), 22 for the length of the sentence (in the mother tongue L1) (10/12), 68 for inability (impossibility) to find the appropriate grammar structure in the target language (L2) (27/41), 17 for lack of the appropriate tool (e.g. glossary) (11/6) and 72 for collocations $(33 / 39)$.

\section{Discussion}

\subsection{An outline of the main problem}

The most problematic issues indicated by both medical translators and medical professionals are prepositions and collocations, with 23 responses in each component. However, if the difficulty score is considered, the number of points attached to colloca- 
tions considerably surpasses the number of points in the case of prepositions (72 points vs. 64, respectively).

Bearing in mind that translation is, to a large extent, a process of creative problem-solving (Karwacka 2016: 58 after Mackenzie 1998) and since the overwhelming majority chose collocations as the most problematic issue, the notion of collocations requires further analysis.

\subsection{Collocations}

Collocations, technically known as conventional syntagms, are the semantico-syntagmatic structures with some extent of combinability (Leśniewska 2008: 111, c.f. Białek 2009: 22). The term, initially introduced by J. R. Firth in the 1950s, is derived from Latin (Takač and Miščin 2013: 237). Definitions of collocations and the criteria for assessing the extent of collocability as well as their strengths are different (cf. Leśniewska 2008: 11, Badziński 2011: 13). Most researchers view them as multi-word phrases in language, including fixed expressions (Gledhill 2000: 1). Linguists distinguish different collocation levels in a given language based on "unpredictability", which is particularly visible in the case of a comparative analysis of two languages (Gledhill 2000).

Studies based on corpus analysis have also contributed to the popularity of the collocation phenomenon. As it becomes easier to access processed information, searching collocations has become simpler and, obviously, less time-consuming. Rapid technological development in data-processing, on the one hand, and a plethora of words that are annually created in the medical field on the other, have also contributed to an increased interest in medical collocations.

As a consequence, the difficulty connected with the proper use of collocations emerged. The results of many studies (e.g. Waller 1993, Howarth 1996, Nasselhauf 2003) clearly indicate that collocation-related problems are observed even at an advanced level of language, which may explain why seven professional translators (88\%) and sixteen physicians (52\%) indicated 
this problem. It is also reflected in the final product which is, in this case, translation.

Collocations constitute one of the most problematic issues both for translators and physicians who are involved in the process of translating their own texts. The notion of collocations is highly complicated, as they may range from totally free to totally fixed phrases and yet there is a huge gap between these two extremes. Generally, however, collocations fall into two major categories, i.e. grammatical and lexical. The first category is composed of a phrase that consists of a dominant word (noun, verb, adjective) and a preposition. Lexical collocations, on the other hand, are normally devoid of infinitives or prepositions and are made up of nouns, verbs, adverbs or adjectives (Badziński 2011).

However, some scientists use a more complex typology, applying different criteria to the term collocation, which as a language phenomenon, is perceived from completely different perspectives. Gledhill (2000: 1) distinguishes three perspectives: statistical/textual, semantic/syntactic and discoursal/rhetorical approaches. According to Gledhill (2000: 2), the first perspective frames collocations as the syntagmatic association of lexemes which prefer the company of another item rather than its synonyms because of usage-related constraints. Gledhill (2000: 2) states:

from the point of view of many corpus linguists, all that separates collocation from mere word co-occurrence is the statistical level at which the researcher is happy to say that the co-occurrence is not accidental. [...] a textual collocation is likely to have a specific textual function or may occur in a rather restricted set of contexts.

The second approach, semantic/syntactic, is related to a more abstract relationship that exists between words and no reference to the frequency of occurrence is made. Therefore, the term collocation is extended from restricted collocations to less conventional notions i.e. grammatical collocation in which gram- 
matical items are mixed with lexical ones (phrasal verbs) and de-lexical verbs (e.g. take a decision) (Gledhill 2000: 7).

As Gledhill (2000: 14) reports after Fernando (1996), the third approach, discoursal/rhetorical, is analyzed from the perspective of performance with the focus on rhetorical effect and no special attention is paid to lexical units or grammar.

Keeping the above typology in mind, the definition of the term collocations adopted for the purpose of the present paper and given in the survey was as follows: phenomena larger than words, which are fixed combinations of lexical items.

Proper communication and dissemination of knowledge must be based on the correct use of collocations as they constitute a key part of the English language and therefore form a rich and complex area which is quite frequently neglected by teachers, students and (even worse), translators themselves.

\subsection{Other issues indicated by both groups of translators}

Aside from the problems with collocations, other issues were indicated. Problems with tenses were reported by both groups, which is surprising in the case of medical translators, due to the fact that all of them had a language background and were graduates of different departments of English studies.

However, it is not surprising that seven physicians reported English tenses as a significant problem. Two of them provided further descriptions and specified the problem in a more detailed manner. The most problematic issue was connected with the use of past tenses, particularly past simple and past perfect. One respondent also noted a problem with using present perfect. It is obvious that unfamiliarity with the proper use of the correct tense may, in fact, disturb the order of the medical procedures in the text, which obviously instantly disqualifies such a paper due to ambiguity and confusion. It may stem from the fact that Polish learners of English are too conservative in following grammar issues and sometimes do not observe the context-related tense usage, which in this case is of paramount importance. It may even be speculated that the excessive use or 
overuse of the past perfect is a common occurrence, which may immediately result in the rejection of a paper by reviewers.

None of the respondents indicated problems connected with the passive voice. It might be partially explained by the fact that passive voice is mainly used in medical texts rather than past simple (rarely in perfect tenses) and therefore the structure is relatively easy. Passive forms in the Polish language (such as obserwowany, zwizualizowany) are most often translated directly into passive in English, hence this is probably why no difficulty was observed in this respect.

A multitude of nouns in medical expressions constituted another problem, since some of them originate from Greek or Latin, whereas others are typically English-derived lexemes. It would appear then that ideally they should not be mixed. However, their practical application shows something completely different (c.f. Badziński 2011). Greek, Latin and English prefixes are frequently placed next to one another, which for translators may pose some difficulty as to which prefix should be chosen. This problem was indicated by three respondents. In Polish, a common problem is related to nouns functioning as attributes. Furthermore, noun phrases in this instance do not only form expressions with two nouns, but they frequently collocate with three or four, which is one of the typical phenomena in specialist medical register. As a result, in one collocation the number of nouns occurring in a linear manner may reach three or four lexemes (sleep apnoea syndrome; cancer pain treatment; stocking-glove distribution deficit). The problem with the nouns may be related to the order of these components and their form, due to the fact that physicians have the tendency to put the plural form in the wrong places (symptom occurrence vs. symptoms occurrence [sic!]). A multitude of nouns may obviously be connected with the text layout and may be dependent on practical issues such as the common occurrence of phrases with of, which may encourage and promote the omission of this preposition by using the linear noun segments as indicated above. What is particularly important here is the fact that the random 
formation of such combinations is absolutely impossible due to the specificity of medical language.

The issue of a multitude of nouns may be part of the collocation category as it can be seen from a strictly grammatical perspective (problems related to the formation of the plural form) or the problem within the collocation itself.

The length of sentences in Polish is significantly different compared to English (Belczyk 2012: 46). Problems in this respect were observed by 18 respondents, which accounts for $46.1 \%$ of the total number of respondents. While English uses relatively shorter sentences with one or two complements, the structures in medical language in Polish are abundant with complements and interjections, often deprived of verbal phrases. Furthermore, the willingness of some authors to collect and place a large amount of information in one sentence often complicates the issue, thus resulting in extremely long structures. Such sentences sound absolutely natural and proper in Polish whereas, when translated into English, the meaning of the sentence becomes vague and blurred, often leading to clumsy and meaningless constructions. Dividing compound sentences partly solves the problem, however, it may result in the omission of crucial information not so much in terms of grammar but rather emphasis.

The lack of an appropriate tool (glossary, dictionary) - as one of the problems indicated by five respondents $(12.8 \%)$ is rather thought-provoking and surprising considering the practically unlimited access to medical databases. Theoretically, glossaries and medical dictionaries should solve this problem so that it should not be observed at all. However, this ideal state was not confirmed by the questionnaire survey. In point of fact, contemporary reference sources and databases (medical databases, parallel and synonymous articles etc.) are numerous.

Wnętrzak (2008) tried to fill in the gap on the market in terms of providing particular field-related dictionaries. Considering the number of lexemes found there, it was partly achieved, yet at some point the publication procedures stopped and were not continued. 
Finding the right grammar structure in English was a problem for 21 of 39 respondents, which may be due to the literal translation of sentences into English, which is still very common practice not only among physicians but also among translators. Impersonal structures probably pose the greatest challenge in this regard, which was reflected by additional opinions provided by three respondents in the survey. The lack of proper structure may be related to the accumulation of nouns, as already discussed above. Consequently, this issue is directly combined with other factors. An additional problem does not necessarily have to be related to the lack of adequate construction - it may be the lack of knowledge in this respect.

Articles, including zero article, and prepositions were also frequently mentioned problematic issues. Although the rules on their detailed use are widely discussed in the literature (Quirk 1997, Swan 2005), their proper use still remains a highly difficult task, as indicted by the survey questionnaire. In the case of Poles who speak English, the problem arises from the fact that articles do not occur in Polish. This is probably due in part to a superficial familiarization with the subject matter, and also to some disregard of the context-dependent phenomenon of countable and uncountable nouns where the given lexeme may occur as countable or uncountable depending on the surrounding lexemes.

In the case of prepositions, problems might be related to the literal translation of these parts of speech by means of calque or the fact that some prepositions occur only in Polish whereas in the equivalent expressions in the English language, such prepositions are not present (wpływać na vs. influence). Another explanation might also be the fact that certain words and phrases should be acquired together with the prepositions which are the integral parts of such phrases. Finally, the difficulties may be related to the use of a different preposition due to context - in other words the use of context-related prepositions (complain about used in the general register vs. complain of which is typical of the medical register). 
The issue of prepositions is also directly related to collocations. This may concern both general language and a highly specialized register. At this point, it is difficult to offer any specific recommendations in this regard, since the phenomenon of the misuse (or the non-use) of prepositions is also closely related to the phenomenon of collocations. It should be stressed that in English the noun declension has a residual form, and cases are expressed by means of word order or, more importantly, by prepositions, of which to, at, for are the most prevalent (Belczyk 2004: 23). When the introduction of the instrumental form appears clumsy, in such situations it can be replaced by another expression (e.g. by means off. The context at this point seems to be very helpful. However, it is not a panacea for all of the difficulties encountered with prepositions, since it is not always possible to make a simple paraphrase to completely eliminate the preposition.

A few comments provided by physicians explicitly suggest that their language knowledge related to their own specialty does not seem to be similar to their knowledge of collocations. Furthermore, despite the correct use of single words, the general meaning of the sentence may be lost due to the erroneous use of collocations. In highly specialized texts (e.g. genetics, bioengineering) the main problem is related to adjectival phrases (as indicated by three respondents in the survey).

Based on the above analysis, it is clear that the "near-native" competence is absolutely required in the case of medical translation where inappropriate structures or words not only distort the meaning, which may have (literally) deadly consequences, but such errors may also discredit scientists. Therefore precision, however trivial it may seem, is of great importance.

\section{Study limitation}

The number of professional translators (eight) may be a study limitation. However, it should be borne in mind that it is difficult to obtain the acceptance and approval of medical translators for study participation (author's own observation). 


\section{Conclusions}

To the best of the author's knowledge, this is the first study in Poland demonstrating the problems and challenges related to the translation of medical texts which has been carried out on the basis of a survey questionnaire distributed simultaneously among active translators and medical professionals in the Republic of Poland. The collected data are interesting due to the fact that the problematic issues are indicated by two completely different groups, both of whom are actively involved in the process of translation. Ignorance of collocations may obviously result in the rejection of a manuscript due to language inadequacy. This in turn, may adversely affect the reputation of the researcher, but, what is even more worrying, it may also be an obstacle to the dissemination of knowledge which under normal circumstances would have been published had it not been for the erroneous use of collocations. Considering their significant role related to the knowledge of medical collocations and their practical use for understanding and conveying medical knowledge internationally, further collocation-related empirical studies should be conducted. Furthermore, it is postulated that collocation-oriented studies should also consider the competence of the translator in the domain of collocations.

\section{References}

Badziński, Arkadiusz (2007). "Traps and problems of medical simultaneous interpreting: notes for interpreters (to be)". Linguistica Silesiana 28: 234-242.

Badziński, Arkadiusz (2011). Medyczny słownik kolokacji. Warszawa: Medipage.

Belczyk, Arkadiusz (2004). Poradnik tłumacza z angielskiego na nasze. Kraków: Idea.

Białek, Ewa (2009). Kolokacja w przekładzie. Studium rosyjsko-polskie. Lublin: Wydawnictwo Uniwersytetu Marii Curie Skłodowskiej.

Džuganová, Bozena (2013). "English medical terminology: Different ways of forming medical terms". JAHR 4/7: 55-69. 
Fernando, Chitra (1996). Idioms and Idiomaticity. Oxford: Oxford University Press.

Gledhill, Christopher (2000). Collocations in Science Writing. Tübingen: Gunter Narr Verlag.

Howarth, Peter (1996). Phraseology in English Academic Writing: Some Implications for Language Learning and Dictionary Making. Tübingen: Niemeyer.

Karwacka, Wioleta (2016). Przekład tekstów medycznych. Gdańsk: Wydawnictwo Uniwersytetu Gdańskiego.

Kokot, Urszula (2001). Metody przekładu niemieckich nazw medycznych na język polski. Katowice: Wydawnictwo Uniwersytetu Śląskiego.

Lee-Jahnke, Hannelore (1998). "Training in medical translation with emphasis on German". In: Henry Fischbach (ed.). Translation and Medicine, Amsterdam - Philadelphia: John Benjamins Publishing, 81-91.

Leśniewska, Justyna (2008). „Dlaczego kolokacje”? In: Maria Jodłowiec (ed.). Nowe perspektywy dydaktyki języków obcych. Kraków: Tertium, 111-117.

Mackenzie, Rosemary (1998). "Creative problem solving and translator training". In: Ann Beylard-Ozeroff, Jana Kralova, Barbara MoserMercer (eds.). Translators' Strategies and Creativity. Amsterdam Philadelphia: John Benjamins, 201-206.

Montalt Resurrecció, Vicent, Maria Gonzales-Davis (2007). Medical Translation Step by Step. Manchester - Kinderhook: St. Jerome Publishing.

Nesselhauf, Nadja (2003). "The use of collocations by advanced learners of English and some implications for teaching". Applied Linguistics 24: 223-242.

Niebrój, Lesław (2010). Bioetyka programów życiowych. Katowice: Śląski Uniwersytet Medyczny w Katowicach.

Pavičić Takač, Visnja, Evelina Miščin (2013). „Exploring the collocational competence of non-native users of medical English". JAHR 4/7: 235-256.

Pilegaard, Morten (2016). "Ethics of informed consent: an applied linguistics perspective”. In: Pilar Ordóñez-López, Nuria Edo-Marzá (eds.). Medical Discourse in Professional, Academic and Popular Settings ("Language at Work"). Bristol-Buffalo-Toronto: Multilingual Matters, 79-102.

Quirk, Randolf, Sidney Greenbaum (1997). A University Grammar of English. Harlow: Longman. 
Swan, Michael (2005). Practical English Usage. Oxford: Oxford University Press.

Waller, Tove (1993). "Characteristics of near-native proficiency in writing”. In: Hakan Ringbom (ed.). Near-Native Proficiency in English. Turku: Abo Akademi, 183-293.

Wnętrzak, Iwona (2008). Słownik urologiczny polsko-niemiecko-angielski. Warszawa: Wydawnictwo DK MEDIA.

Wysocka, Maria (2001). „Podkody angielszczyzny medycznej”. In: Janusz Arabski (ed.). Języki specjalistyczne. Język biznesu. Katowice: WSZMIJO, 116-121.

\author{
Arkadiusz Badziński \\ ORCID iD: 0000-0001-7019-6131 \\ University of Silesia in Katowice \\ Institute of Linguistics \\ Gen. Stefana Grota-Roweckiego 5 \\ 41-205 Sosnowiec \\ Poland \\ arkadiusz.badzinski@us.edu.p1
}

